\title{
VOICES OF MALAYSIAN INDIAN WRITERS WRITING IN ENGLISH
}

\section{Shangeetha R.K.}

English Language Department, Faculty of Languages and Linguistics, University of Malaya, Kuala Lumpur, MALAYSIA

Email: shangeetha@um.edu.my

Published online: 30 October 2020

To cite this article: Shangeetha, R.K. 2020. Voices of Malaysian Indian writers writing in English. Kajian Malaysia 38(2): 25-59. https://doi.org/10.21315/km2020.38.2.2

To link to this article: https://doi.org/10.21315/km2020.38.2.2

\begin{abstract}
This article brings together a compilation of poems, short stories and novels written by Malaysian Indian writers from 1940 to 2018. These verse and prose forms collected here were all written in English within the last 80 years. In fact, in the contemporary Malaysian literary scene, the number of works by Malaysian Indian writers writing in English, has increased compared to the previous volumes which were primarily dominated by writers such as Cecil Rajendra, K.S. Maniam and M. Shanmughalingam. It is interesting to note that the interest of writing poetry and prose among the younger Malaysian Indian writers is on the rise with publications from younger poets and writers such as Paul GnanaSelvam and Cheryl Ann Fernando. In Malaysia, poetry and prose written by Malaysian Indian writers in English is diversifying with many promising new talents. Departing from the Malaysian Indian diaspora, the emerging themes of these lesser-known writers are more liberal. As such, the main aim of this article is to map out the cartography of Malaysian Indian works in these three genres; poem, short story and novel, and identify the main thematic concerns in the writings.
\end{abstract}

Keywords: Malaysian Indian history, Malaysian Indian poetry and prose, Malaysian literary tradition

\section{INTRODUCTION}

This article charts the history of poems, short stories and novels written by Malaysian Indian writers in English and identifies the pertinent themes emerging from these writers. This article employs a qualitative approach using textual 
analysis. The focus of this article is the publications of poems, short stories and novels over several decades written in English emerging from the Malaysian Indian community. As such, the data would be from poems, short stories and novels published between 1940 and 2018 in English by Malaysian Indians residing in and outside Malaysia. The data is collected from 1940 onwards as this is the earliest evidence of publication from this community. It begins with mapping out the cartography of published works of well-known as well as obscure writers in the mentioned genres chronologically based on specific time frames. This is done through tracing and listing down all the works published by Malaysian Indian writers in English. In all, 139 poems and 102 short stories as well as 37 novels were read and catalogued based on pertinent issues dealt in the various published works. It then highlights the main themes the writers focused on, according to specific time-frames, in order to identify the changes in the narratives from works written before independence to 2018. The parameter of textual analysis is confined only to the pertinent issues found in the various works of Malaysian Indian writers due to the sheer amount of published works. The article is divided into three sections. The first section focuses on poetry while the second and third sections highlight short stories and novels respectively. Each section discusses the emerging themes from pre-independence era up to 2018. The intent of this article is primarily to map out the Malaysian Indian literary works, with the aim of contributing to the larger tradition of Malaysian literary writings in English. Furthermore, through this article, many obscure Malaysian Indian writers would be known to the literary world.

\section{LANGUAGE HISTORY OF MALAYSIA}

Unlike any other countries, Malaysia is a country where a minimum of four languages predominate: Malay, English, Chinese and Tamil, with multiple dialects and colloquialism according to its region. During the 15th century, the multicultural population had been evident, drawing roots from the Sultanate of Melaka which rose to become one of the most prominent ports bringing in entrepreneurs, merchants and scholars from neighbouring kingdoms. Due to this, many people started to settle and form new communities here. However, the downfall of Melaka brought about the occupation of Portuguese (1511), followed by the Dutch (1641) and the British in early 19th century.

Platt and Weber (1980) mentioned that the formation of English language in Malaysia took place in the late 18th and early 19th century due to British settlements in Penang, Singapore and Melaka. Large scale immigrants were brought in from India partly due to the development of tin mining and later rubber estate to supplement the local labour (Kaur 2003; Sandhu 1969). The colonial 
government's policy of specific economic role in a way resulted in a change in the education system. The communities formed here were given the education in their own languages while only a handful of people were given the privilege of an English education to assist in the clerical duties (Puthucheary 2009). Thus, English medium schools like Penang Free School were formed in 1816. Although English medium schools were established, only parents that could afford to send their children attended these schools. Apart from that, the passing of the 1969 National Language Bill in the House of Representatives proclaimed bahasa Melayu as the national language. The implementation of the National Language Bill in 1969 required "the full conversion (other than primary schools using Chinese or Tamil as medium of instruction) of all English primary and secondary schools to the Malay or national medium" (Tham 2001, 41). This bill proclaimed bahasa Melayu as the only official and national language, thus limiting the use of English language in national schools and establishing the bahasa Melayu as the main lingua franca.

Each of these colonialised presence left a permanent mark not only on the landscapes but also in the languages here. The English language in Malaya is a legacy left behind by the British. Many Malaysians, including Malaysian Indians, have embraced the language. Although Malay is the national medium of instruction in schools, English is still widely used. Even though English is widely used, not all Malaysians are proficient in the language, resulting in minimal published works written in English, especially from the Indian community.

\section{MAPPING THE HISTORY OF MALAYSIAN INDIAN WRITINGS IN ENGLISH}

Literary texts such as verse and prose forms have always been seen as important reflectors of the social dynamics of communities in any country. Most studies and discussions of the literary texts emerging from a single community are more focussed on separating out strands that consolidate a particular set of attitudes and perspectives that distinguishes the singularity of that community rather than focussing on the diversities that the community displays. The pertinent themes identified in the published works spanning more than a half-century of writing in all three genres that were catalogued reflect such diversities.

The ensuing discussion presents a view of the Malaysian Indian community's pattern of literary activity based on the publication of writings in the genre of poetry, short stories and novels with its beginnings in the early 1940s to 2018. Undoubtedly, the development of verse and prose writings in English language by Malaysian Indians lags behind their counterparts in India, who began writing in the 1830s. This is due to the education in English medium, 
although established in 1816, could only be accessed by the rich. The Indians in Malaysia were mostly Tamil educated due to the fact that the majority were from the working class community that were originally brought as indentured labourers during British colonialism.

It was estimated that until 1957, about 4.2 million Indians immigrated into Malaya where 91.3\% were from South India and 65.3\% were labourers (Sandhu 1969, 159). Apart from the labouring class of migrants who were mainly from the rural areas of South India, there was also a large scale migration of Englisheducated Indians who played the mediatory role between the labouring class and the comprador European class of planters, establishing a community of middleclass Indians. Thus, there is a hegemonic representation of the Indian community in Malaysia as it is not only found on the grounds of working class community alone. As such, Malaysian Indian writings reflect not only the working class community but the middle and upper classes as well. The ensuing section chooses to provide a glimpse into the body of poetry and prose writings in English that have emerged from the creative imaginary of the Malaysian Indian community and its pertinent themes as a result of the early communal chronicles.

Figure 1 shows the total number of publication by Malayan/Malaysian Indian writers from the earliest work in 1940 to 2018. It is arranged according to specific time-frames. The bar graph serves as an overview of the number of verse and prose written by the Malaysian Indian community.

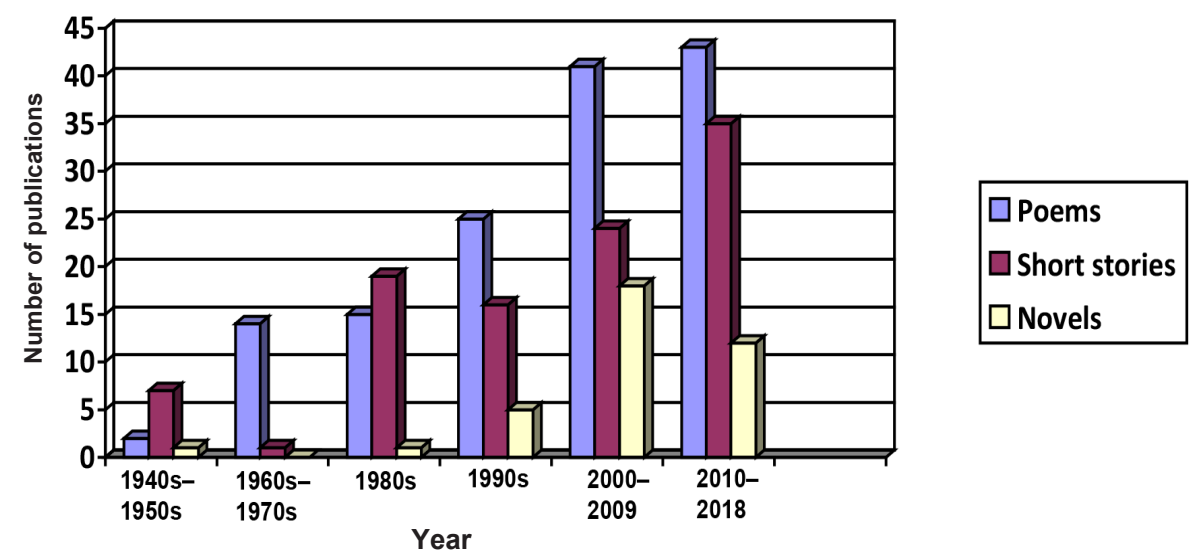

Figure 1: Collection of English literary works written by Malaysian Indians. 


\section{POEMS}

\section{0-1979: Imagery of Rural Life and Social Issues}

As mentioned earlier, literary works in English by Malaysian Indians can be categorised as fairly new as the earliest works of poetry writing in English by a Malayan Indian writer is Edwin Thumboo's poem, "Kelong" (1940) as well as his poetry collection, Rib of Earth (1940). Rib of Earth is a collection of poems on the beauty of nature and meaning of life. The collection was published by Lloyd Fernando, printed by Straits Printers in Singapore. As for Edwin Thumboo's first poem, "Kelong", which describes scenes in rural life, it was considered as "the earliest example of the successful deployment of Malayan imagery within the body of a locally written work and is one of the earliest pieces of evidence from Malaya that English literature was beginning to put forth new leaves" (De Souza 2001, 10). Here De Souza is referring to the inclusion of local images in the writing of literary works by Malayan writers. Previously, the style of writing in Malaya was very much influenced by colonial writers as English language writers from Malaya were the product of a literature syllabus that was "centred on the study of the English literary tradition from Shakespeare to Milton and the great humanistic tradition of European culture taught as if their only concern was with the universal themes of love, fear, birth and death" (Zawiah 2003, 4-5). Besides Thumboo's first collection of poems, there were no other literary publications in the 1950s by Malayan Indian writers. This could be partly due to the limited avenue for publishing in English language in Malaya and also the fact that Malaya was experiencing Communist insurgency at that time. In 1961, T. Wignesan published Tracks of a Tramp, an anthology of poems written from 1951 to 1960 . His poems reflect colonial writings with the only exception of "The Bogey in the Tall Tree of the Long Name" which has reference to Malaya and has a Malayan Indian character. The poem reveals the prejudices of the colonial character and the othering of the Malayans. Unlike the writings of Thumboo, Wignesan's poems are a reflective of a British education system. In 1962, the Federation of Malaya deprived Wignesan of his Malayan citizenship, forcing him to relocate to Europe. He is currently residing in France, making him perhaps the first of the Malayan Indian writers in the Malaysian diaspora. In 1963, Murugasu Shanmughalingam published "At Berserah" which highlights the price one has to pay for development in Berserah, a fishing village in Pahang, Malaysia. Similar to Thumboo, Shanmughalingam's vivid description of a tranquil rural Malay village of the coast of Malaya brings forth the local way of life.

The 1960s also saw the emergence of a poet who would go on to become known as one of the most prolific writers from the Malaysian Indian community, this being Cecil Rajendra. Rajendra's first published collection of poems, Embryo 
(1965), and his subsequent collection, Eros and Ashes (1975), are a selection of romantic poems centred on the themes of love and loneliness while Bones and Feathers (1978) revolves around poems that highlight issues of ecological ruin, poverty and oppression. Another emerging poet of this era is Pretam Kaur. Her poems are very much centred on the experiences of the poor Indian immigrants in Malaysia. Although the thematic pattern of Kaur's work focuses on the earlier migration experience, Kaur includes Malaysian imagery, giving her work a local identity. For example, in "Homecide" (1967), Kaur describes a broken home in Malaysia, nevertheless it is a place of comfort and belonging while "Relics" (1967) gives images of the poor conditions of an Indian immigrant who is venerated back home but lives as a poor guard in Malaysia. Her poem "Gone with the Peacocks" (1976) illustrates a romanticised motherland, India; formed by the first generation Indians in Malaysia which is not shared by the next generation.

K.S. Maniam, another prolific writer who would go on to make a mark in prose writing, first published a number of individual poems in 1968 in Singapore through the efforts of Edwin Thumboo who compiled Malaysian poetry. K.S. Maniam's early poetry writing, which focused more on the theme of moulding youth as well as the significance of a woman, appeared in Poetry Singapore, a journal of original works in English from Singapore/Malaysia, edited by Thumboo. Unfortunately, it ceased publication after only two issues in 1968, closing an avenue for Malaysian poets to publish their work. Table 1.1 in Appendix 1 illustrates individual poems as well as collections of poetry published by Malaysian Indians in the 1940s to 1970s.

\section{0-1999: Social Issues, Relationships and Identity}

The 1980s saw the return of Cecil Rajendra's poetic activity as illustrated in Table 1.2 in Appendix 1 with his anthologies of poem published in various sources. There were no other poets who made significant contribution in poetry writing as compared to Rajendra. His writing throughout the 1980s was mostly on social issues that afflict not only Malaysia but Third World countries as well. Rajendra's collections of poems are internationally praised and he is acknowledged as "Malaysia's best-known poet...a one-man pressure group, committed to awakening people to the social evils that beset his country and the world in general" (Addison 1983). His themes concern a range of issues such as oppression, exploitation, justice, poverty, corruption, peace and the environment. Cecil Rajendra's collection of poems throughout the 1990s again exploits on social issues that inflict underdeveloped countries, namely issues of ecology, war and refugees. Similarly, in the works of M. Shanmughalingam, the theme that is most noticeable is the negative effects of development as he has penned down many poems which centre on this theme. M. Shanmughalingam's poem "Heir 
Conditioning" (1995), which emphasises the price of progress on each generation, was one of the poems used in the Malaysian Literature component textbook for lower secondary school students until 2015. Apart from these established poets, poetic activities of the 1990s saw a slightly more participation of Malaysian Indians. Malachi Edwin Vethamani published a number of individual poems in a university journal, placing emphasis on relationships and mixed marriages. At the tail end of the 1990s, a new female poetic voice emerged from this group of male poets, Charlene Rajendran, as shown in Table 1.3 in Appendix 1. She published her debut anthology of poems entitled Mangosteen Crumble in 1999 which deals with issues of identity. The background of her poems is Malaysia and Rajendra highlights the different cultures, languages and practices in Malaysia through her witty use of language.

\section{0-2017: Environment Conservation, Family, Relationships, Women Empowerment, Nature and Technology}

The millennium years have seen an increase in the emergence of many writers of a younger generation of Malaysian Indians. Conservation of the environment still takes precedence with poets such as Cecil Rajendra, Charlene Rajendran and Jerome Kugan choosing to write mainly on this theme. Nevertheless, poets writing in the 21 st century also seem to be concerned on themes such as family and relationships. Cecil Rajendra's "Little Flower" (2006) and "Untitled Poem" (2003) are on family and relationship respectively, while Leonard Jeyam centres his poems on family and Charlene Rajendran's "A Question of Rights" (2003) is on relationship.

Sharanya Manivannan, although an Indian national, was raised in Malaysia for most part of her childhood (from the age of 5 to 22) making all her publication of poems before 2007 part of the Malaysian canonical works as her writings were influenced by her Malaysian surrounding. The notable theme in Manivannan's poetry writing is on the equal rights of women. Although "Poem" was published in 2008, it was written when she was 17 years old while still living in Malaysia. She also represented Malaysia at Poetry Parnassus (a non-competitive poetic Olympics conducted in the UK) in 2012, thus making her work part of the Malaysian literature. While Manivannan's writings are distinctly feminist, Shivani Sivagurunathan, who started publishing since 2007, centres her poems mostly on nature. Thus, later publications of poems from these budding poets reflect diversity in themes that move away from family and relationships. Table 1.4 in Appendix 1 shows the full list of collection of poems published from 2000 to 2009. One of the most contributed collections of poems in this era is the collection of poetry written by Malachi Edwin Vethamani. His collection of poems, Complicated Lives (2016) features 82 poems addressing 
various issues, particularly themes concerning family love and loneliness. The first half of this collection explores the relationship of a mother and a child. Vethamani also gives a dynamic view of the child's thoughts towards his mother. Wong Phui Nam (2016) states that the poet clearly gives contrasting image of his mother during her young age up to her old age, suffering from both physical and mental abilities. The second half of Vethamani's collection is based on his memories of living in Brickfields, Kuala Lumpur. It includes other themes such as the loss of individuals on board the MH17 Malaysian flight as well as the emphasis on national integration through "It Was a Wondrous Sight". In Vethamani's latest collection of poems, Life Happens (2017), he again addresses similar issues as his previous collection such as family affection, longing, separation, gay relationship, adultery, death as well as poems that touch on nature. Apart from these recurrent themes, Vethamani also chooses to address the consciousness of change through the lens of science and technology. Within the collection, some of his individual poems touch on information technology such as the chore of changing passwords in "Digital Stress", using the medium of Facebook to end relationships in "Press Delete" and to reconnect with old friends in "Reunion" as well as clicking the "Like" button in Facebook for meaningless wishes in "Happy Labour Day". Furthermore, "I Will Text You" highlights how the digital world has taken over our lives when mobile phones become the preference in communication rather than face to face conversation.

Apart from Vethamani, Melizarani T. Selva is another established female poet who has also gained much international recognition. Being a runner up at both The National Singapore Slam 2013 and Readers Festival 2014 Poetry Slam, she has proven to be a talented young poet who started writing from the age of six. Her first book of poems titled Taboo (2015) made the top-10 bestseller list of Malaysia's largest online bookstore, MPH. The poems in this book address the dilemmas faced by women through the subject of taboos, identity and empowerment in the Malaysian Indian society. Most of her poems are based on her own experiences and her humorous writing style, injecting Malaysian slang brings a different approach to how poems are written by young Malaysians today, representing the voice of the minority. Apart from established poets like Vethamani and Selva, lesser-known poets such as Sashi Vadivale and Paul GnanaSelvam started publishing from 2014 and 2015 respectively as shown in Table 1.5 in Appendix 1 with diversified themes. Vadivale poems reflect on desires and injustice while GnanaSelvam penned on tranquillity and hope.

\section{Pertinent Themes}

Poems penned between 1940s and 1970s were very much on nature, life in general, negative effects of development, poverty, environment and migration issues using 
local imageries. Themes on social issues dominated the 1980s and 1990s that centre on poverty and exploitation of Malaysia and other underdeveloped countries as well as highlighting the downside of development. Apart from that, there is a shift to issues that concern national integration in the 1990s with emphasis on mixed marriages and identity issues in the Malaysian society. On the other hand, although conservation of the environment is still an issue that is championed in the millennium, there is a move towards themes of family, relationships and woman empowerment. The current poets have consciously included use of information technology in Malaysia as well as highlighting issues considered taboo in the Malaysian culture. Younger generation poets such as Melizarani Selva and Sharanya Manivannan are becoming more vocal in their thoughts compared to the older and more established group of poets such as Maniam and Shanmughalingam.

\section{SHORT STORIES}

\section{0-1979: Social Problems of the Working Class Indian Community}

The earliest works of writing in English by Malayan Indian writers were a series of seven short stories by Sinnathamby Rajaratnam in the 1940s (refer to Table 2.1 in Appendix 2). Rajaratnam, a Sri Lankan Tamil descent, wrote mainly on the issues of social problems experienced by the Indian rural community. In 1948, Rajaratnam's short story, "The Tiger" (1942) was quoted as "an example of modern Malayan writing" in the Mirror, a monthly international review (Ng 2011). Apart from Rajaratnam's writings, there were no other publications of short stories between 1940s and 1960s. The next publication of a short story by a Malaysian Indian was nearly three decades later. "The Eagles" (1976) is K.S. Maniam's first published short story describing the estate life in the 1950s. Similar to Rajaratnam's theme, Maniam also focuses his story on the working life of labourers in rubber plantation in Malaysia. Apart from Maniam, there were no other publications from Malaysian Indians in the 1970s as shown in Table 2.2 in Appendix 2.

\section{0-1989: Social Issues of Working Class Indians and Rural Malaysian Community Lifestyle}

It was the early 1980s that revealed a hive of Malaysian Indian literary activity and here K.S. Maniam remains the most prominent. The early 1980 s also saw the emergence of female voices as illustrated in Table 2.3 in Appendix 2. The setting for all the short stories written in the 1980s is very much in Malaysia and the protagonists tend to be from one ethnic background only, which is the 
author's own ethnic group. This is very much evident in K.S. Maniam, Jessie Michael and S. Mangayakarasi's stories. Through Maniam's works, readers in the 1980s are mainly exposed to the Tamil working class community although the Malaysian Indian community encompasses sub-ethnic groups such as Malayalee, Telugu and Punjabi, to name a few. Most of the stories deal with the Tamil ethnic group only as the majority of the short stories represented in the 1980s was written by K.S. Maniam, as exemplified in Table 2.3 in Appendix 2. Maniam projects the concerns of the Tamil community through his writings. Similarly, M. Shanmughalingam's first published short story "Birthday" (1981) narrates the expectations in the Tamil community for the birth of a baby boy in a family. In all these stories, there is minimal engagement with the other major ethnic groups in Malaysia such as Malays and Chinese. Therefore, most of these stories are not a representative of the inter-ethnic culture dynamism in Malaysia. However, it is pertinent to note that among these group of writers, all of Pretam Kaur's short stories are set against the backdrop of a multicultural environment in the 1980s in Malaysia thus, it is not surprising that all of her four short stories are used as the prescribed texts for the Sijil Tinggi Persekolahan Malaysia Literature in English syllabus, an elective national examination paper which is equivalent to the A Levels (Malaysian Examinations Council 2012). Preetam Kaur's short stories mainly depict the culture and life of rural communities in Malaysia, centring on Punjabi, Malay, Chinese and Tamil families, thus integrating an understanding of the various cultures in Malaysia. Thus, unlike her other counterparts, Kaur's stories expose readers to the importance of national integration which seems lacking in the other representation of stories in the 1980s.

\section{0-1999: Social Problems and Family Relationships in Indian Community}

In the 1990s, a few more Malaysian Indian writers began to come to the fore to articulate their thoughts on life in Malaysia through their short stories. Compared to the 1980s, although writers who published their short stories in the 1990s saw more involvement of Indian writers, their work was irregular as illustrated in Table 2.4 in Appendix 2. This could be attributed to the fact that one of the publishing avenues for Malaysians writing in English, the Heinemann Asian Writers Series, was closed down in late 1980s, resulting in publishing Malaysian works difficult (Maniam 2012). Therefore, the short stories that were all published in 1991 were actually the winning entries of a NST-Shell Short Story Competition that was held between 1989 and 1990. These stories were anthologised by Kee Tuan Chye under a local publishing company. The stories mostly centred on family relationships in the Indian community.

Among the writers of the 1990s, it is only K.S. Maniam who has shown consistency in publishing not only poems but short stories as well. Maniam writes 
his stories "to present through the immediate and local preoccupations the more universalised picture of man and society in conflict" (Maniam 2001, 264). This issue is not likely found in the themes of the other writers. Although Maniam's stories focus on the Tamil community alone, he does integrate the story of the nation and its problems within the stories of the families narrated. Malachi Edwin Vethamani's stories, on the other hand, centre on family relationships in the Indian society, focussing on love and adultery. Vethamani's two short stories, "The Kiss" (1995) and "Husband Material" (1996) were published in the literary section of the national newspaper. Among these budding new writers, it is pertinent to note that Marie Gerrina Louis's "Bequest of Love" (1991) centres on the relationship of a Malay family with Chinese and Indian characters. Thus, unlike all the other writers whose protagonists come from their own ethnic background, Louis integrates the relationship between the major races in Malaysia through her stories. Writing in the 1990s, Louis, similar to Pretam Kaur, moves away from the comfort zone of centring her characters within her ethnicity and makes an effort to produce a Malaysian story.

\section{0-2018: Family Relationships, Sexuality, Cultural Issues and Women Empowerment}

The millennium years have been the era in which the prose form reigned supreme in the Malaysian Indian creative imagination as illustrated in Tables 2.5 and 2.6 in Appendix 2. Similar to the genre of poetry, many obscure Malaysian Indian writers emerged in this era as evident in Table 2.5. Most of the series of short story publications after 2000 focus primarily on themes of family and relationships. Shanmughalingam, Mahadevan and Mathew Thomas centred their stories on families, mostly on individuals who are affected negatively through their family relationships. Similarly Shalini Nayar and Mercy Thomas wrote on more intimate relationships such as the downside of arranged marriages and break-up in relationships. Dysfunctional family relationships seem to be the most noticeable theme for most of those who wrote in the 2000s. On the other hand, upcoming writer, Devena Kasinathan's intriguing style of writing in "The Story-Catcher" (2004), a fantasy genre, brings a fresh look to the way writing is approached by young Malaysian Indians today. Her story focuses on the conversation between a half-human, half-elve girl and a wizard about the difficulties of writing a good story that appeal to both children and adults. Kasinathan's fantasy genre moves away from the dysfunctional family theme that is most notable in this era.

Devena Kasinathan continued her engaging style of writing through "The Shoplifter" (2010), a conversation between a woman and a therapist about her habit of taking things from her friends' houses with a surprising twist at the end. On the other hand, Vethamani's collection of 12 short stories titled Coitus 
Interruptus (2018) looks into various issues relating to the theme of racial intolerance, relationship and sexuality. One of the prominent issues in this book is the idea of homosexuality. The writer specifically chose to address the idea of a gay community which is considered taboo in the Indian community. This is apparent in 5 out of the 12 stories written. On the other hand, M. Shanmughalingam's latest collection of short stories, Marriage and Mutton Curry (2018), highlights the marriage protocol in the Tamil-Jaffna community. In addition, another writer who also highlights the issues facing the Malaysian Indian community is Paul GnanaSelvam. GnanaSelvam's individual short story, "The Ride" (2014) focuses on the importance of keeping up appearances in society. His collection of short stories, Latha's Christmas (2013), does not only address the issue of migration but also looks into superstitious beliefs. This is prevalent in the short story entitled "The Shadow Boy". Similarly, Shanthini Venugopal's "Chicken or the Egg?" (2011), as well as, Maheswary Ponnusamy's "Desperate Measures" (2014) centre on the theme of superstitions. On the other hand, Saras Manickam's "It's All Right, Auntie" (2011) focuses on the marital issues that are swept under the carpet with detrimental effects to the child.

It is worth mentioning that many lesser known writers are able to come to prominence from the year 2010 onwards through local publishing companies such as Fixi Novo, Word Works and MPH Group Publishing that publish short story anthologies. These local publishing companies are opening avenues for fiction writings to be published hence recognising and encouraging many young talents. Although there are many new talents emerging in the past decade, these writers still very much focus their stories on issues concerning the Tamil community in Malaysia. Gopalan Sellan's But My House was Here and Other Stories (2011) is a collection of short stories regarding estate life and beyond while Subashini Navaratnam's "Girl Power" (2014) centres on the social restrictions of women in the Malaysian Tamil society. Sharmila Ganesan's engaging story on the test of faith against forbidden food in the Hindu religion in "French Fries for Aunty Kamalam" (2014) is relatable to many readers. Adding to this latest collection of new writers is a promising teenage writer, Dhanyeta Devi. Dhanyeta's "It Only Takes One" (2018) is a move away from dysfunctional family relationship theme that many writers seem to focus on. Her story focuses on the importance of family members and being there for one another through a time-travel tale. Written from the viewpoint of a young girl, Dhanyeta brings a new look to how writing is approached through creative imagination, an approach similar to Devena Kasinathan.

Short stories written throughout the 1940s to 1980 s seem to mostly focus on the social problems faced by the rural Indian community in Malaysia. This could be attributed to the fact that there were only six writers who published their work during this time, hence producing similar theme in their writings. There 
is a shift to the theme in the 1990s as writings published in this decade seem to centre on dysfunctional families and relationships in the Indian community focusing on love, adultery and friendship. The theme of dysfunctional families and relationships still takes precedence in the stories published in the early years of the millennium and issues on the social problems in the Indian community have also re-emerged. As more lesser-known writers started publishing, there is also a focus on the theme of superstitious beliefs and sexuality in the Malaysian Indian community. Going into the millennium, writers have become more open in addressing homosexuality issues that are considered taboo in the Indian society.

\section{NOVELS}

\section{0-1999: Patriotism and Social Problems in the Indian Community}

Among the early work in the publication of novels is Gurchan Singh's Singa: Lion of Malaya (1949). Singh's memoir which was published in 1949 mainly centres on patriotism. The book is a personal narrative of the author of the Malayan Resistance Movement led by him during the Japanese occupation in Malaya. Publications of novels before 1990 by Malaysian Indian writers in English can scarcely be found as illustrated in Table 3.1 in Appendix 3. This could be due to Malaya struggling to achieve its independence and forming its own government in the 1950s and 1960s. Furthermore, the government policy of not recognising any literary work written in languages other than bahasa Melayu for the National Writer award from 1971 onwards (Tee 1999) could have also discouraged many writers to write in the English language.

The 1980s is significant for the publication of the first and only Malaysian Indian novel, The Return (1981) by K.S. Maniam. This novel is seen as the quintessential representation of the Malaysian Indian route to nationhood. Similar to the setting of his short stories, Maniam's novel is very much centred in the mono-ethnic foregrounding of characterisations where the major characters are from the Tamil community. Maniam centres all of his stories on the history and problems of the working class Tamil community in Malaysia in order to create awareness of the plight of the Indian diasporic community in Malaysia. Through this novel, one becomes aware of social problems faced by the Malaysian Indian community; however Maniam's readers are only exposed to one sub-ethnicity of the Indian society, which is the working class Tamil community. The Indians in Malaysia are a heterogeneous ethnic group, with Tamils forming the majority, followed by Telugus and Malayalees, as well as Sri Lankan Tamils, Chittys, Punjabis, Gujaratis and Sindhis (Sandhu 1993; Arasaratnam 1993; Ravichandran 2009). Perhaps due to their small numbers as compared to the Tamil ethnicity, the 
other sub-ethnic minority voices are not well-represented in the writings of the Malaysian Indian society.

Novels published in the 1990 s were also limited as shown in Table 3.2 in Appendix 3. The noticeable gap in the publication of novels by Malaysian Indian writers from 1981 to 1993 could be due to the fact that Malaysia, being a multi-lingual nation and English not being the mother-tongue of a majority of its races, has a limited readership among its people. This could have resulted in de-motivating earlier writers from writing in English. This view is supported by Wong Pui Nam who stated in a 1998 interview, that Malaysians are not proficient enough in the English language to show interest in works written in English as "English can account for no more than two or three percent of the population - a situation not helped by the average Malaysian's lack of interest in reading" (Daizal 2001, 243). Wong's statement is also corroborated by The National Literacy Survey conducted by the National Library in 1996 which revealed that in a year, Malaysians read an average of only two books. In addition, there is limited avenue for publishing books in English in Malaysia. Quayum (2003, xvi) states that "publishing a book is an extremely challenging task since publishers avoid, as is generally expected in a profit-driven capitalist economy, publishing works that are likely to incur loss". Maniam's writings that were written before 2000 were mostly published by London based Scoob Books which discontinued publishing Malaysian works after 2000, closing yet another avenue for publication in English (Maniam 2012). However, local publishing companies like Silverfish Books (formed in 1999 as an independent shop concentrating on Malaysian writing in English), Maya Press and AMK Interaksi are some of the other avenues that gave life to Malaysian writers writing in English. Apart from that, Singapore also became another avenue for Malaysian to publish their work. Marie Gerrina Louis, the most accomplished writer in this decade with two novels, published her work through Heinemann Asia in Singapore.

The theme in the 1990s very much centred in the mono-ethnic foregrounding of characterisations. For example, Maniam's novel, In a Far Country (1993), narrates the experiences of an Indian family; addressing the issue of finding a home in Malaysia and seeking a sense of belonging while Marie Gerrina Louis's The Road to Chandibole (1994) deals with the experiences of the Indian community during the communist insurgency. Her second book, Junos (1995), is also a mono-ethnic setting as it tells the story of a North Indian immigrant family in Singapore during the 1950s. Apart from these veteran writers, two other writers to emerge towards the end of this post-independence era are Uma Mahendran and R. Thambipillay. Similarly, Uma Mahendran's The Twice Born (1998), which chronicles the journey of a child psychiatrist and a 5-yearold autistic boy, is also foregrounded on mono-ethnicity. The story goes back and forth from the past events in India to present-day Malaysia. Unlike the other 
writers of the 1990s, R. Thambipillay's God's Little Acre (1948-1960), published in 1998 chronicles the commemorative events during Malaya's communist insurgency. Similar to Gurchan Singh's theme on patriotism, Thambipillay pays tribute to those who defended the country during Malaya's emergency period.

\section{0 to 2018: Family Relationships, Socio-Cultural Issues, Detective Work, Politics and Education}

Works published in the beginning of the millennium (refer to Table 3.3 in Appendix 3) mainly focused on issues of dysfunctional family relationships. The majority of the writers mostly centred their narration on how family relationship affects the protagonists, always with a negative outcome. However, it was noted that a few of these writers have chosen to focus their subject matter on an altogether different theme. For example, writers such as Shamini Flint chose to focus her writing on detective series for young adults while R. Thambipillay, as mentioned before, wrote on the fallen heroes in the Malayan police force during the emergency period. There is also a slight shift to the mono-ethnic setting of the earlier works where later novels were written with a more multi-racial characterisation. This is very much evident in Maniam's Between Lives (2003), where there was a conscious effort on his part to include Malay and Chinese characters, although the main focus was on two very strong Malaysian Indian female protagonists. This book can be considered as Maniam's Malaysian novel where he gives voice to all the three major races in Malaysia.

The millennium has also proven to be the era of the Malaysian Indian female novelists. Unlike the earlier work in all genres which were dominated by male writers, women are getting more involved in articulating their experiences and this is especially attested in the growing number of novels that are published by women in the millennium. Together with this, the millennium era also brings a shift in the trend of Malaysian Indian writing. There is a more eclectic representation of Malaysian voices. These current writers have a broader canvas where the issues and settings move from national to transnational landscapes. For example, Rani Manicka, Shoba Mano and Shamini Flint are able to capture an international physical setting where their stories are set not only in various locations but in different cultures as well. Manicka's Touching Earth (2005) is about the lives of Balinese twins in London while Mano's The Prodigal Child (2005) deals with American and Asian Culture set in Vietnam. Furthermore, Manicka's latest novel, Black Jack (2013) is unlike all her earlier novels, as her latest writing is a paranormal fantasy that deals with teenagers. On the other hand, Shamini Flint, as mentioned earlier, entered the creative stage bringing with her a host of novels in the detective genre, which is not only set in neighbouring countries like Singapore and Indonesia but also India and China. Writers such as 
Manicka, Mano and Flint engage their characters beyond local ethnic interactions. Flint's publication of a young adult novel, Ten (2009), although centres on a conservative Malaysian Indian family, deals with biracial issues as well, as the protagonist is of mixed parentage; having an Indian mother and an English father. Unlike Flint who engages her readers to a multi-ethnic society, Preeta Samarasan, who had made headway in Europe in 2009, and hailed as the newest voice to emerge from the Malaysian Indian community with vivid creativity through her debut novel Evening is the Whole Day (2008), still focuses very much on social issues faced by the Indian community. Samarasan highlights the class prejudices within the Tamil community through the treatment of the working class in the hands of the middle-class. Although most of these writers have gone on to centre their stories on an international setting as their background, the prevalent theme is still very much focused on mono-ethnic foregrounding as evident in the works of Muthammal Palanisamy, Aneeta Sundararaj, Devika Bhai, Saradha Narayanan and Preeta Samarasan. What seems to be lacking here is the inclusion of a multicultural ethnicity of Malaysia. Likewise, Dave Anthony's Love and Struggle: Beyond the Rubber Estates (2012), which narrates the struggles of the Indian plantation workers in the hands of the British and Japanese government, is also foregrounded in a mono-ethnicity setting. However, unlike K.S. Maniam's stories of the struggles of the Tamil community, this novel focuses more on the love story among the plantation workers. On the contrary, unlike many of his diasporic counterparts who choose to write during the rule of British Malaya and Japanese occupation, Sunil Nair's When All the Lights are Stripped Away (2012) is a breath of fresh air as he has chosen to focus on contemporary Malaysia. His setting is based on the hustle and bustle of Kuala Lumpur and the quiet town of Muar in Johor. Nair's characters are a reflective of the Malaysian society and his story centres on the political aspirations of a minority community in Malaysia, particularly the Malayalee sub-ethnic Indian community. Although the story revolves around a wealthy upper middle class Malayalee family, it moves away from the mono-ethnic foregrounding that is often found in the majority of works written by Malaysian Indians. Nair presents multi-racial characterisations with the inclusion of cultures from the major races in Malaysia. He has also moved away from focussing on the struggles of the working class community and ventured into a political sub-plot. On the other hand, Cecil Rajendra's novel, No Bed of Roses: The Rose Chan Story (2013), a biography of a Malaysian dancer, centres on the life of a Chinese striptease dancer in Kuala Lumpur and Singapore in the $1950 \mathrm{~s}$ to $1970 \mathrm{~s}$. It is pertinent to note that Rajendra's protagonist is not from the author's own background. Thus, we see a shift in the focus from the writer's own background to centring the theme on another ethnic background. Even the subject matter is quite controversial in Malaysia as the main character is a striptease dancer, something which is considered taboo in Malaysia. Among these 
established writers, there is also a new young writer, Cheryl Ann Fernando, who published her novel, "T for Teacher" (2017) which chronicles her experiences of teaching in a rural school in Malaysia. While Fernando's story highlights much of the school issues of students struggling to master the English language, the older generation writers are still caught in the mono-ethnic foregrounding mode of characterisation of the working and middle class Indian community as discussed earlier. With publication of novels from writers such as Sunil Nair, Cecil Rajendra, Shamini Flint and Cheryl Fernando as shown in Table 3.4 in Appendix 3, there is a shift from the mono-ethnic foregrounding to the inter-ethnic culture dynamism in Malaysia with characters from other ethnicity playing pivotal roles in the stories.

\section{Pertinent Themes}

Although the publication of novels started extremely slow, with only two published novels by Malaysian Indians prior to 1990, centring on the theme of patriotism and social problems of the Tamil working class community, it picked up pace from the 1990s onwards. However the theme still very much focussed on the issues faced by the Indian community. With the dawn of the 21 st century, there seems to be a constant publication of works from many young Malaysian Indian writers. The introduction of literature as a compulsory component of English in the secondary school curriculum by the Ministry of Education in the late 1990s could be a contributing factor, apart from the fact that a few of this current generation of Malaysian Indian writers are based overseas and publish their books for an international audience. Similar to short stories, many of the novels published in the millennia seem to focus on the theme of dysfunctional family relationships. In addition, there are still writers who continue to address the struggles of the working and middle class community in Malaysia. The most notable exception to the writers in this era is Shamini Flint whose publication of ten novels centred on the crime genre, which moved away from the norm. Furthermore, writers like Sunil Nair and Cherly Fernando also moved away from the usual theme by emphasising on the political aspirations in the Indian community and issues faced by students learning English in Malaysia respectively. On the whole, in the later works of writers, there is more inclusion of a multi-racial and globalised setting rather than focussing on a mono-ethnicity setting only. For example, the current writers' settings do not only reflect the Japanese occupation, emergency period and estate workers, they consciously address racial tensions, multi-ethnicity and political situations in Malaysia. As such, these writers, who are slowly moving away from mono-ethnic engagements, are being recognised in the international setting as they are able to capture the complex nature of ethnic relations in Malaysia. 


\section{CONCLUSION}

With younger writers coming to the forefront to publish their works, there is a more "Malaysian experience" reflecting Malaysia as a multicultural country and not merely on one particularly Indian defined experience. Thus, there is a shift in the works of Malaysian Indian writings to represent Malaysian voices. Although many of this current generation of Malaysian Indians write from overseas, the issues dealt in the work very much concern the Malaysian society. One of the reasons many upcoming writers choose to publish overseas is due to their work not being recognised in Malaysia as the result of the nationalistic sentiments of writing in the national language, bahasa Melayu. However, these writers are Malaysians at heart as many of them voice out issues that deal with Malaysian diversity.

The works listed in Appendices 1, 2 and 3 are by no means exhaustive as there are likely more literary works in English in the various genres by Malaysian Indian writers. However, the material presented heretofore aims toward showing a significant proliferation of a community of Malaysian Indian writers. It also aims at presenting the thematic issues of a community that is often thought to be in a state of exile and estrange. While undoubtedly, one would find issues central to the Indian diasporic experience such as treatment of different classes among the Indian community, intergenerational conflicts and the recurrent issues of identity, there is a move to capture concerns and settings from national to transnational and global landscapes as discussed earlier.

\section{ACKNOWLEDGEMENTS}

This work was supported by the University of Malaya under Grant [BK009-2017]. 

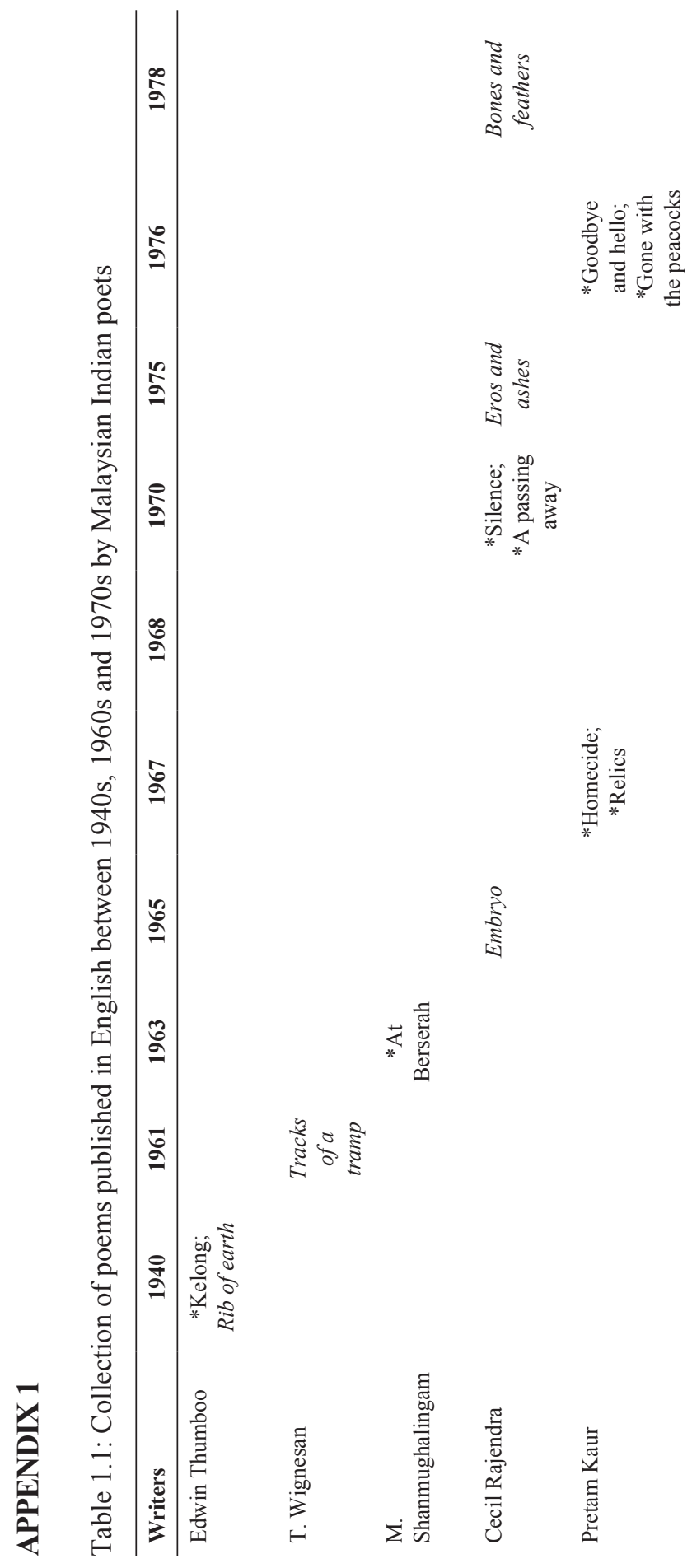

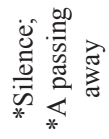
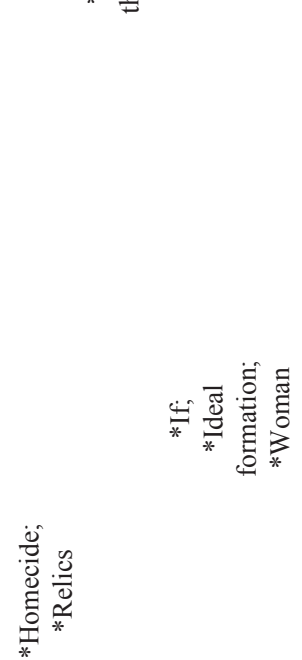

है

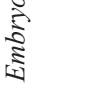


Shangeetha R.K.

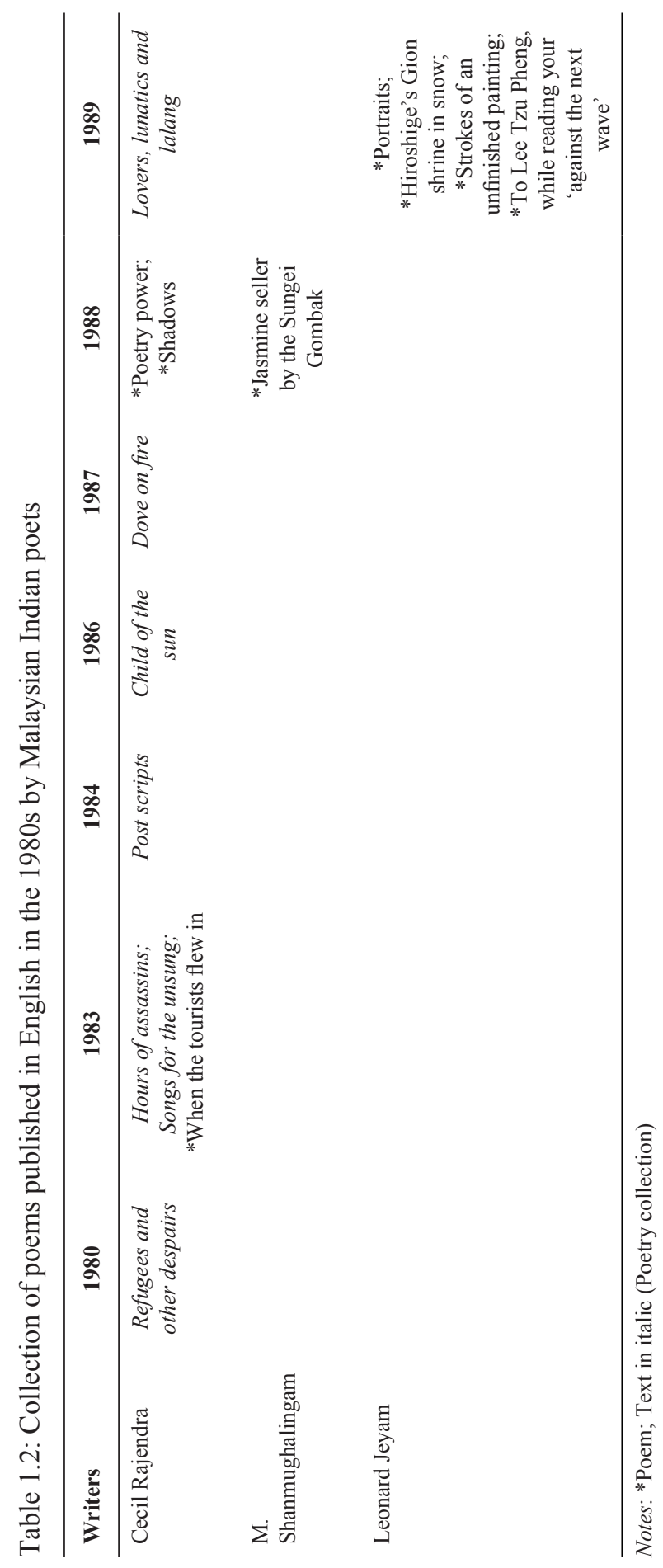




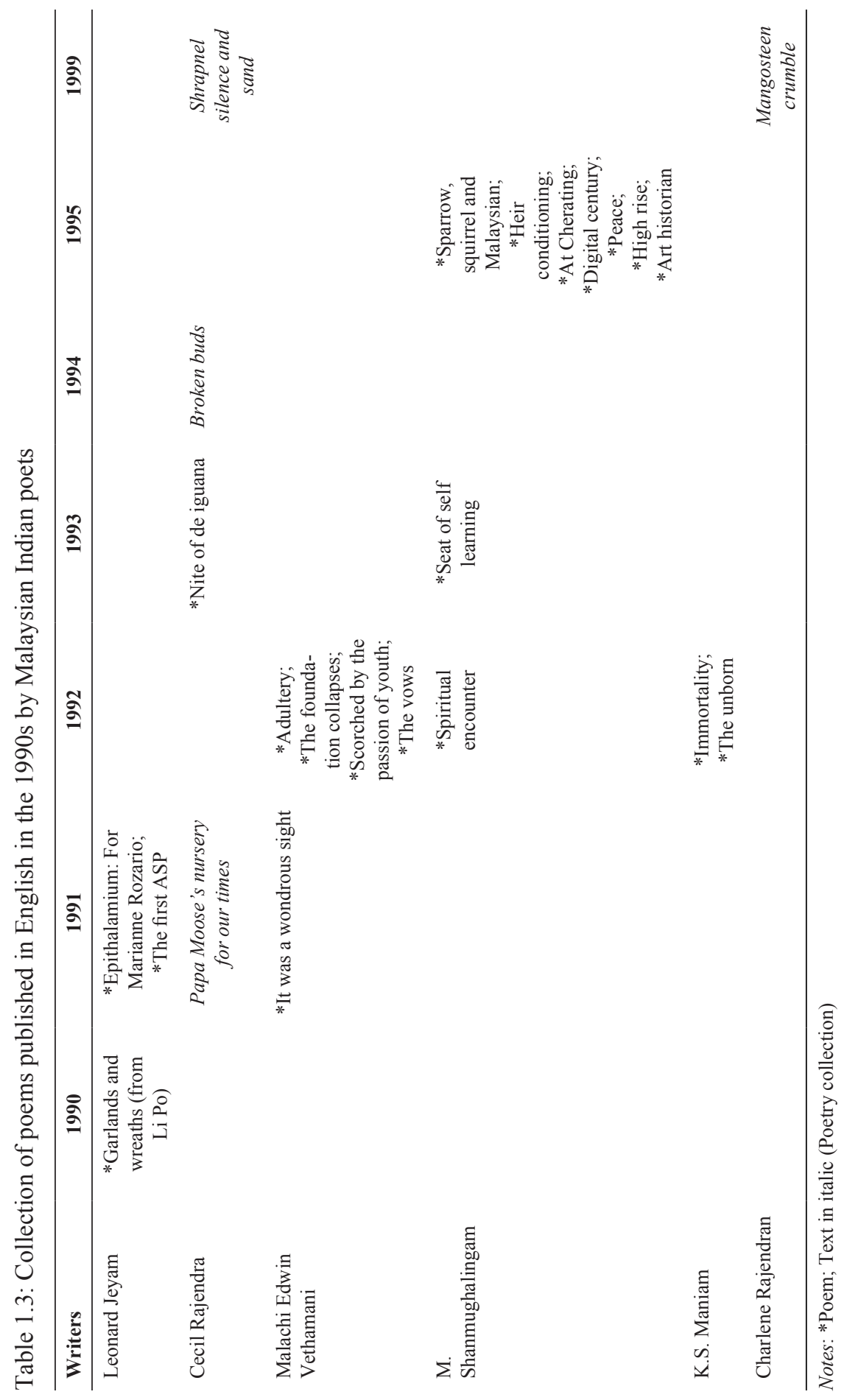


Shangeetha R.K.

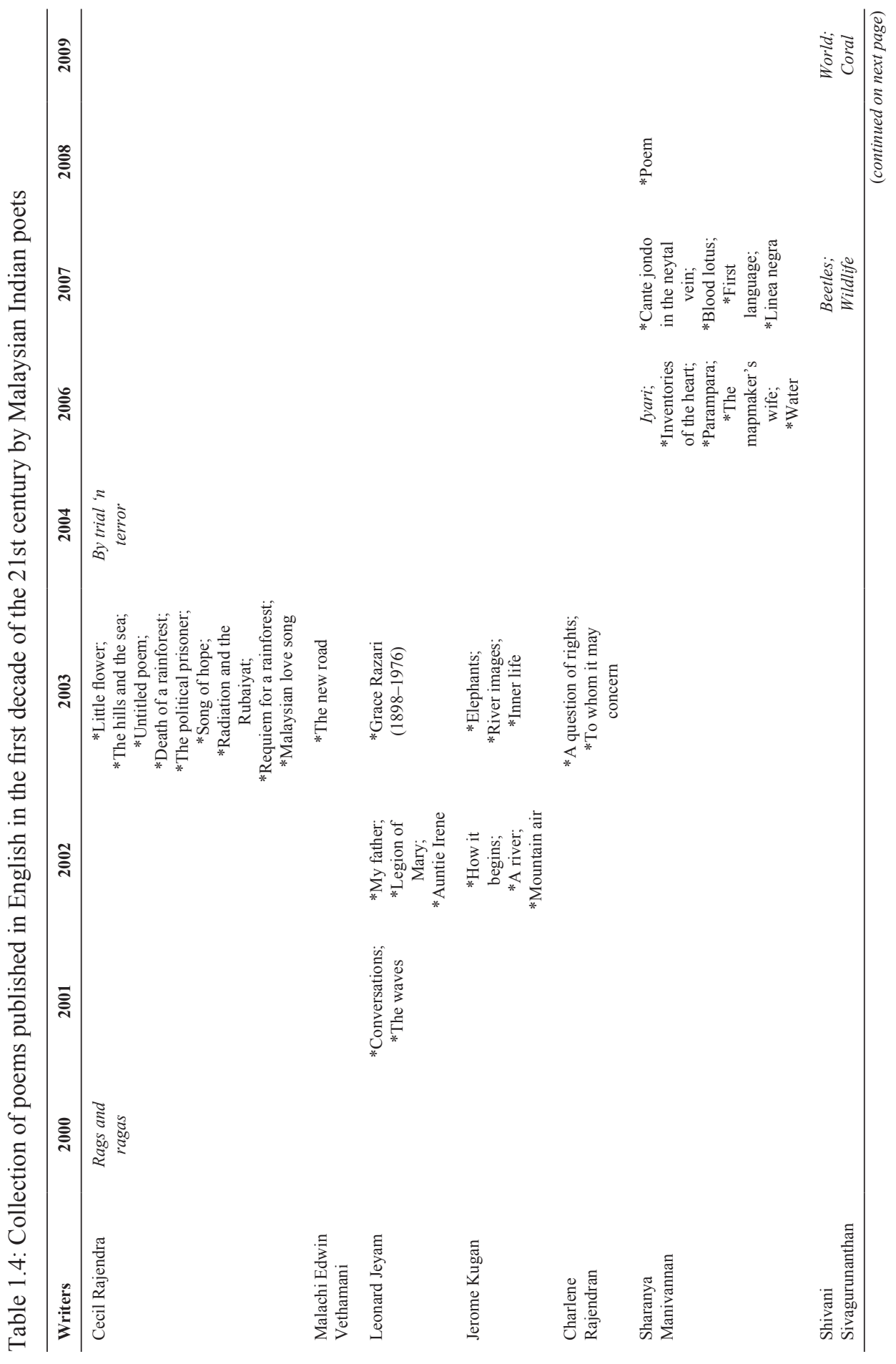




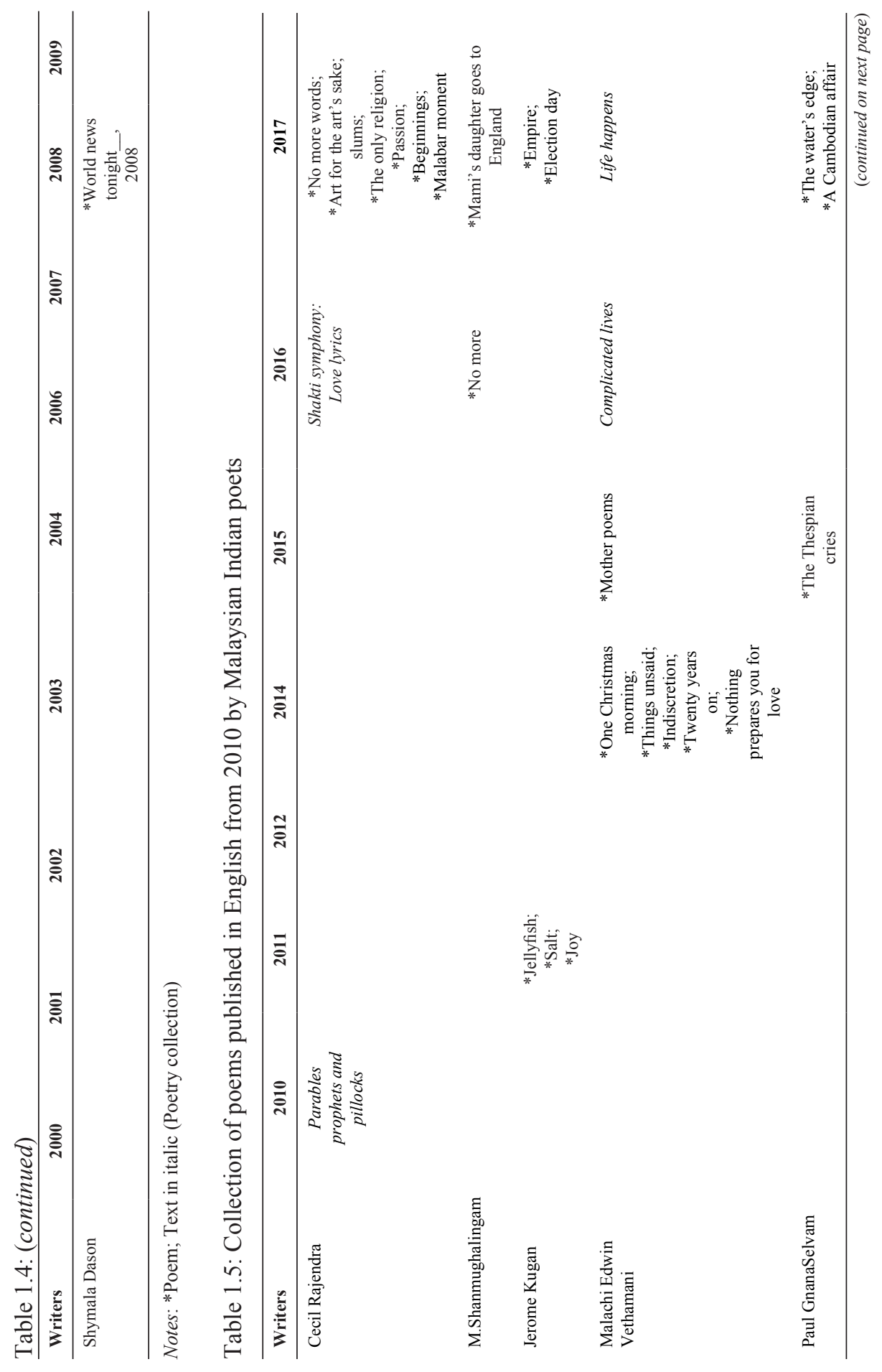


Shangeetha R.K.

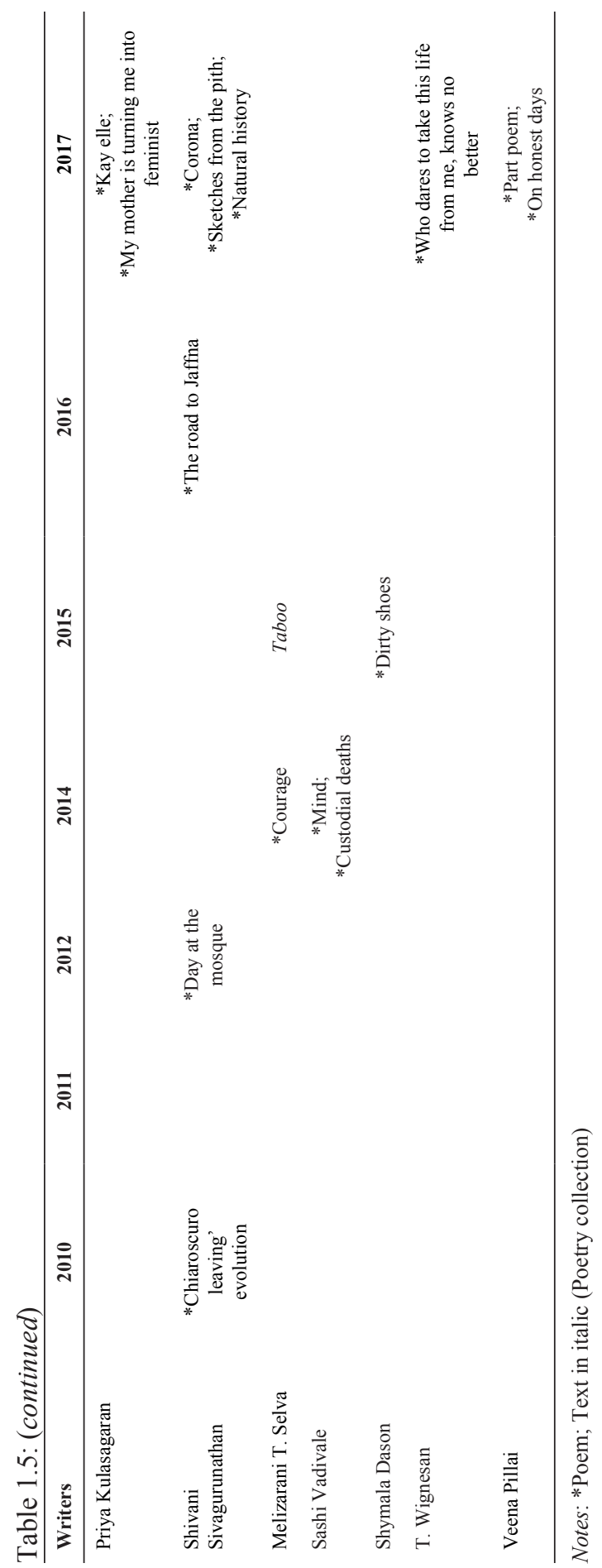




\section{APPENDIX 2}

Table 2.1: Short stories published in 1940s English by Malayan Indian writer

\begin{tabular}{lcccc}
\hline Writer & 1941 & 1942 & 1946 & 1947 \\
\hline $\begin{array}{l}\text { Sinnathamby } \\
\text { Rajaratnam }\end{array}$ & $\begin{array}{c}\text { Famine; } \\
\text { Locust; } \\
\text { What has to be; } \\
\text { Drought }\end{array}$ & The tiger & The stars & Terrorist \\
& & & & \\
\hline
\end{tabular}

Table 2.2: Short stories published in English in the 1970s by Malaysian Indian writer

\begin{tabular}{lc}
\hline Writer & $\mathbf{1 9 7 6}$ \\
\hline K.S. Maniam & The eagles \\
\hline
\end{tabular}


Shangeetha R.K.

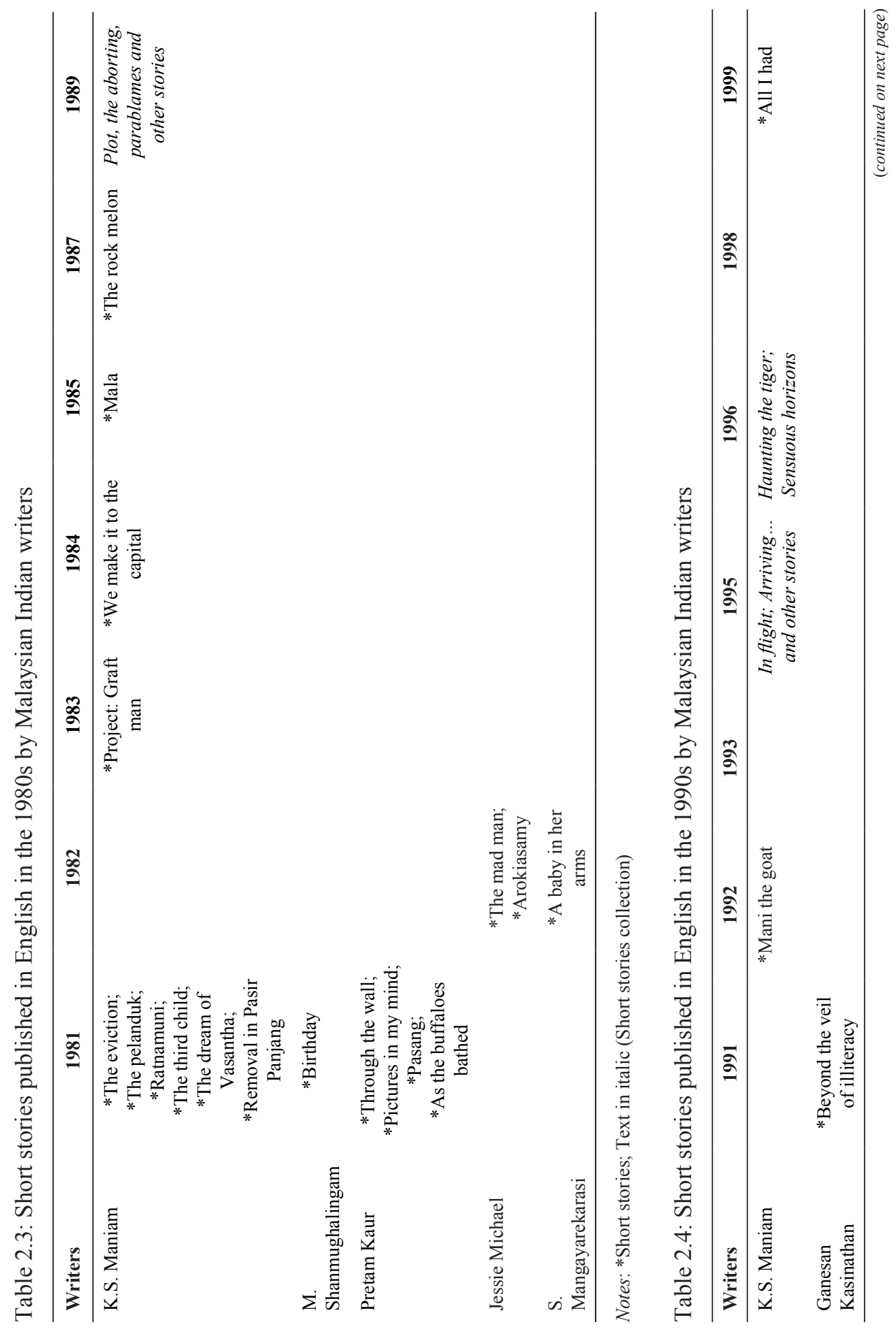




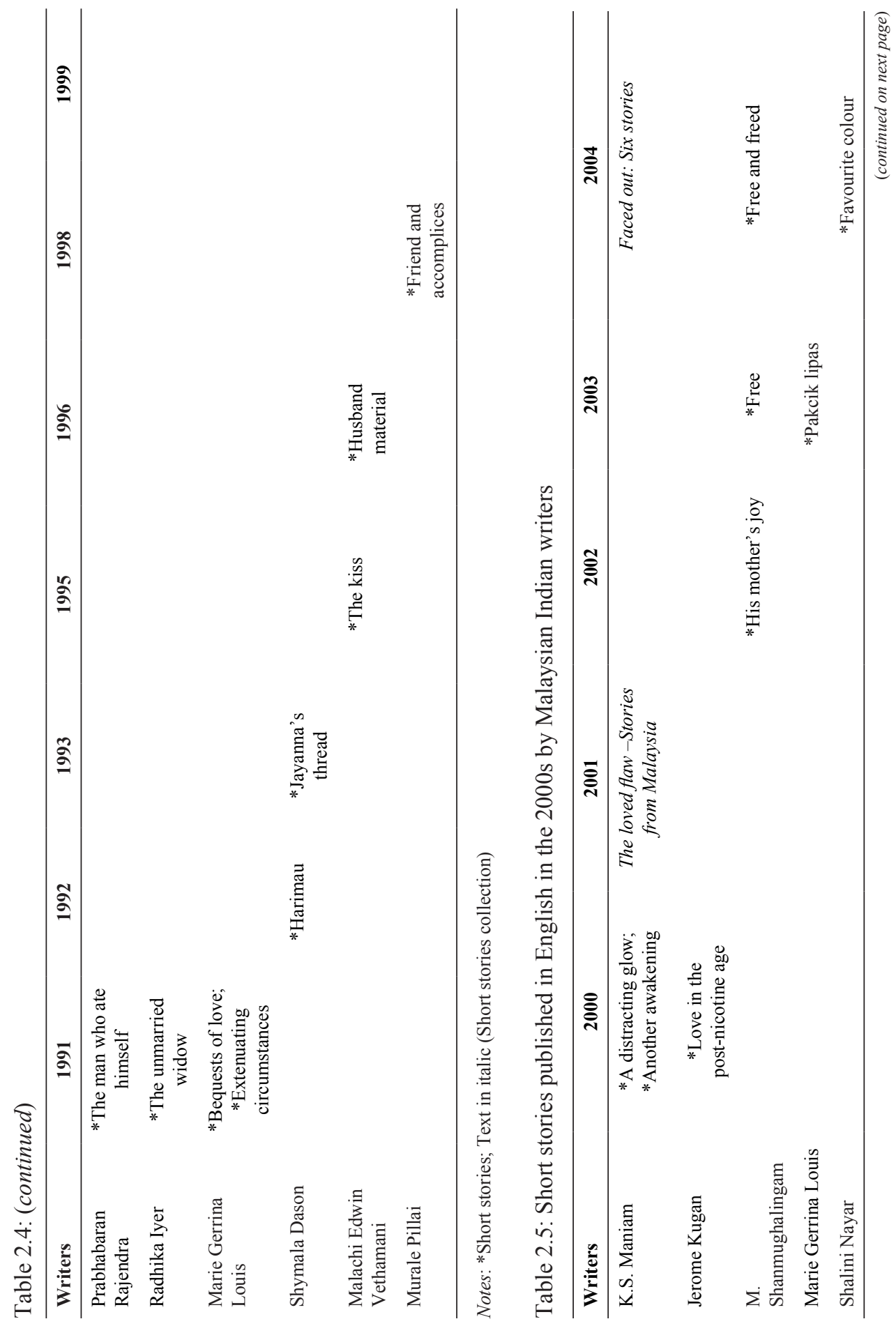


Shangeetha R.K.

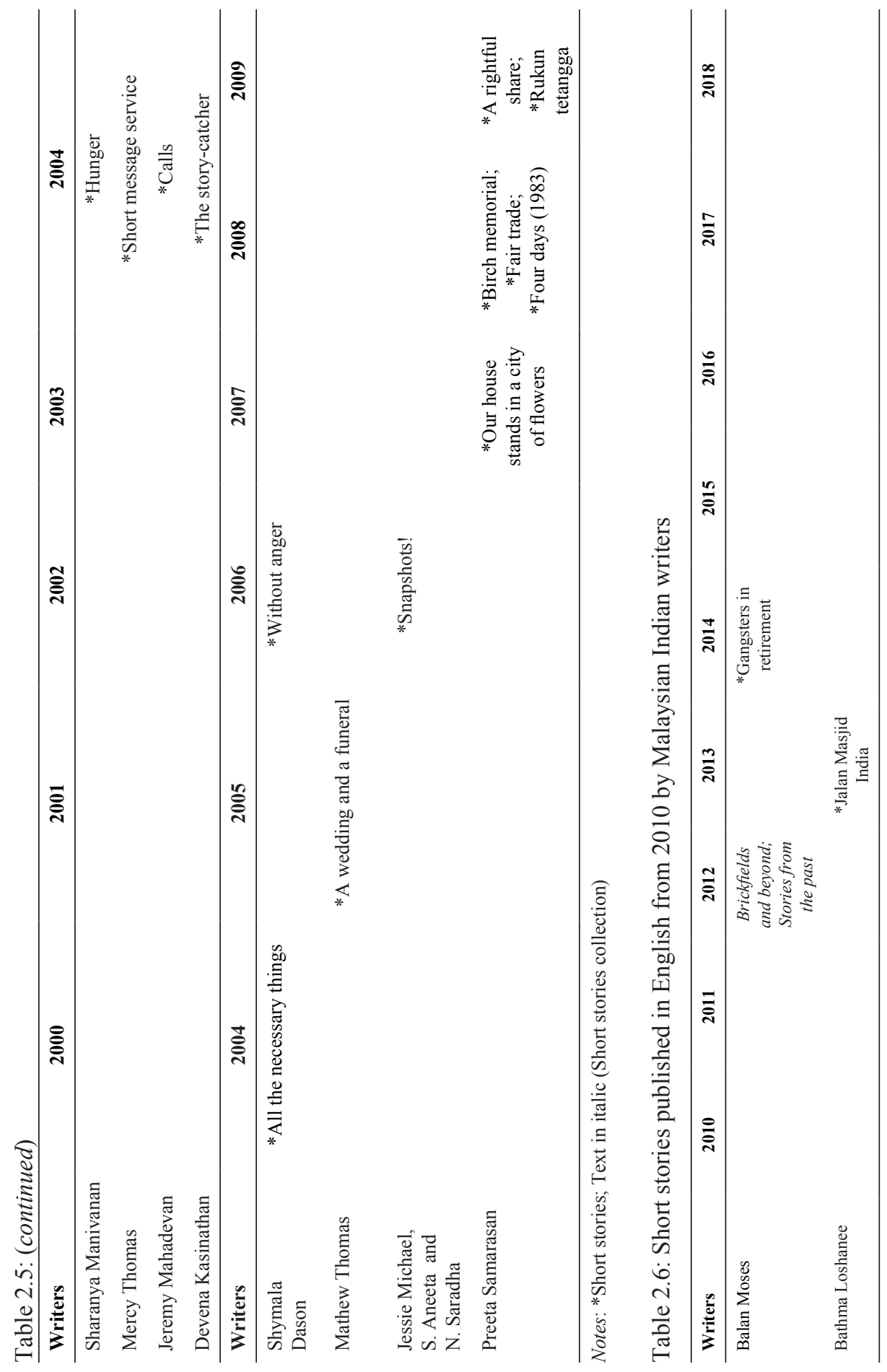




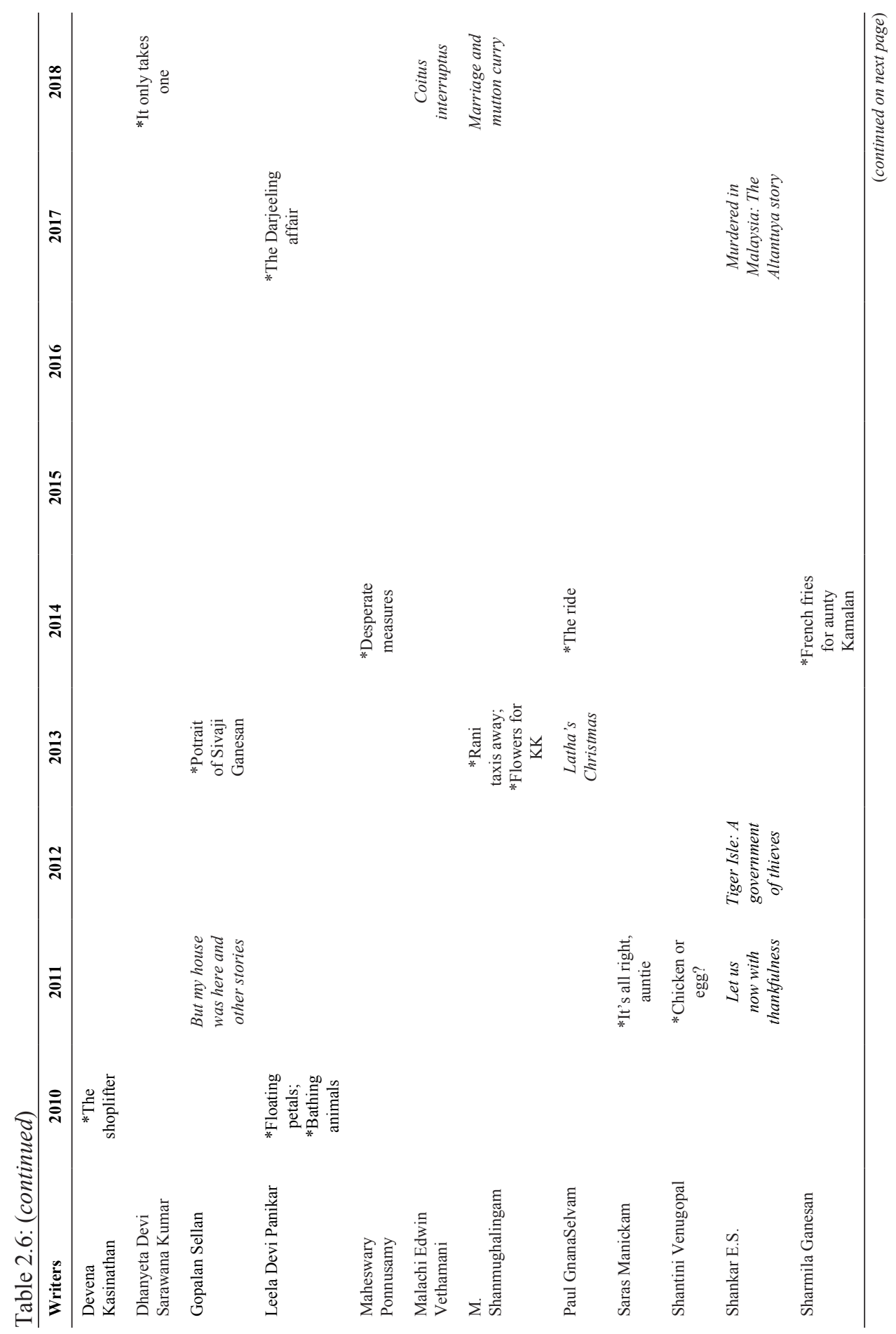


Shangeetha R.K.

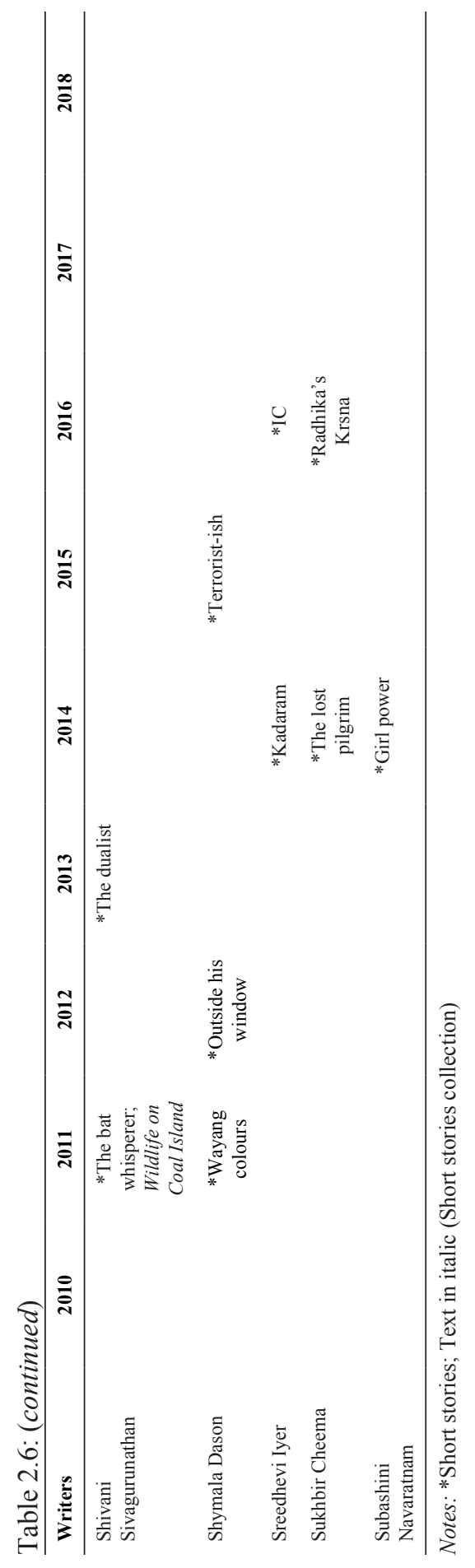




\section{APPENDIX 3}

Table 3.1: Novels published in English before 1990 by Malaysian Indian writers

\begin{tabular}{lcc}
\hline Authors & 1949 & 1981 \\
\hline Gurchan Singh & Singa $:$ Lion of Malaya & \\
K.S. Maniam & & The return \\
\hline
\end{tabular}

Table 3.2: Novels published in English in the 1990s by Malaysian Indian writers

\begin{tabular}{lcccc}
\hline Authors & 1993 & 1994 & 1995 & 1998 \\
\hline K.S. Maniam & In a far country & & \\
Marie Gerrina & & $\begin{array}{l}\text { The road to } \\
\text { Chandibole }\end{array}$ & Junos & \\
$\begin{array}{l}\text { Uma Mahendran } \\
\text { R. Thambipillay }\end{array}$ & & & The twice born \\
\hline
\end{tabular}


Shangeetha R.K.

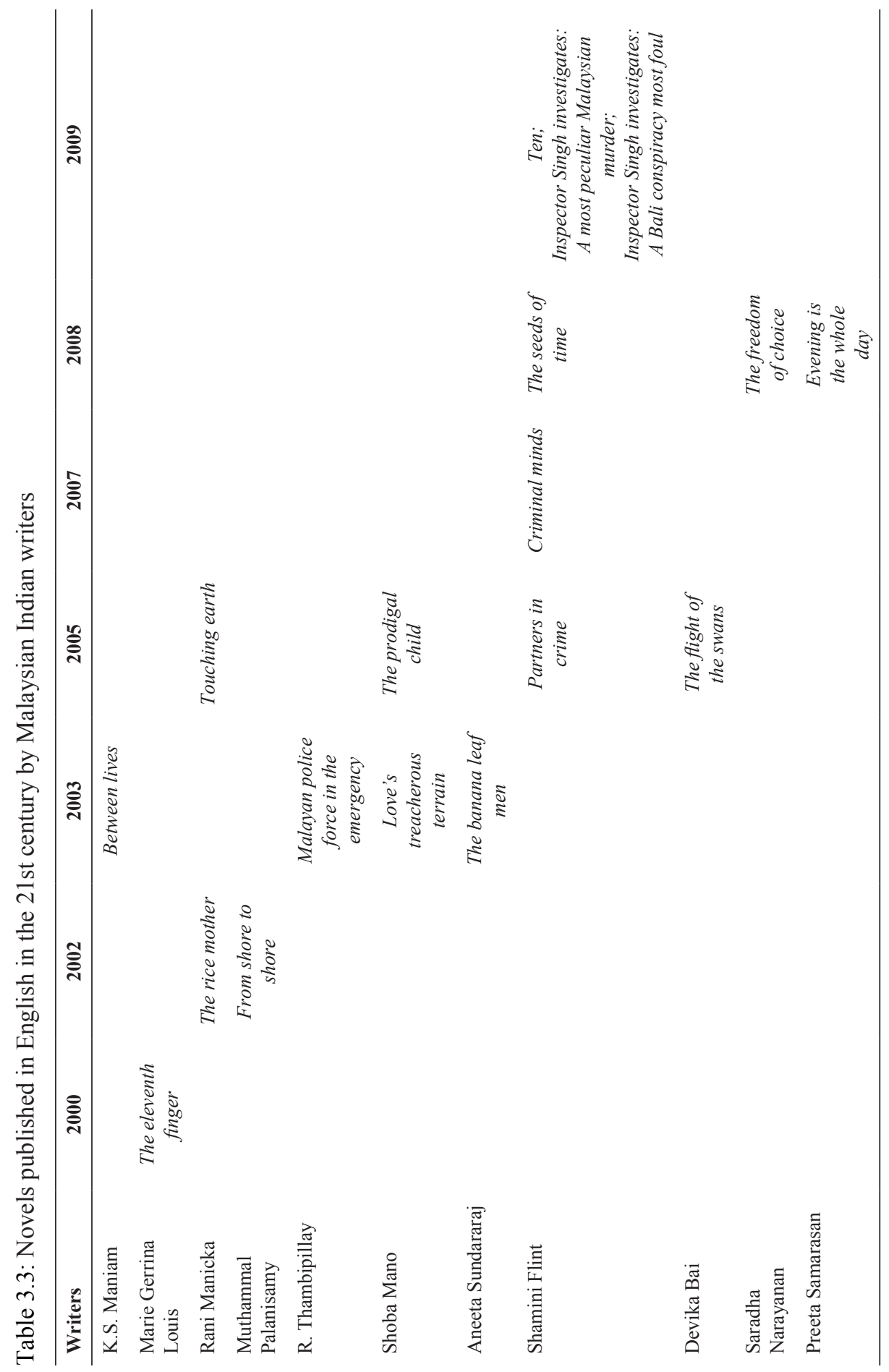




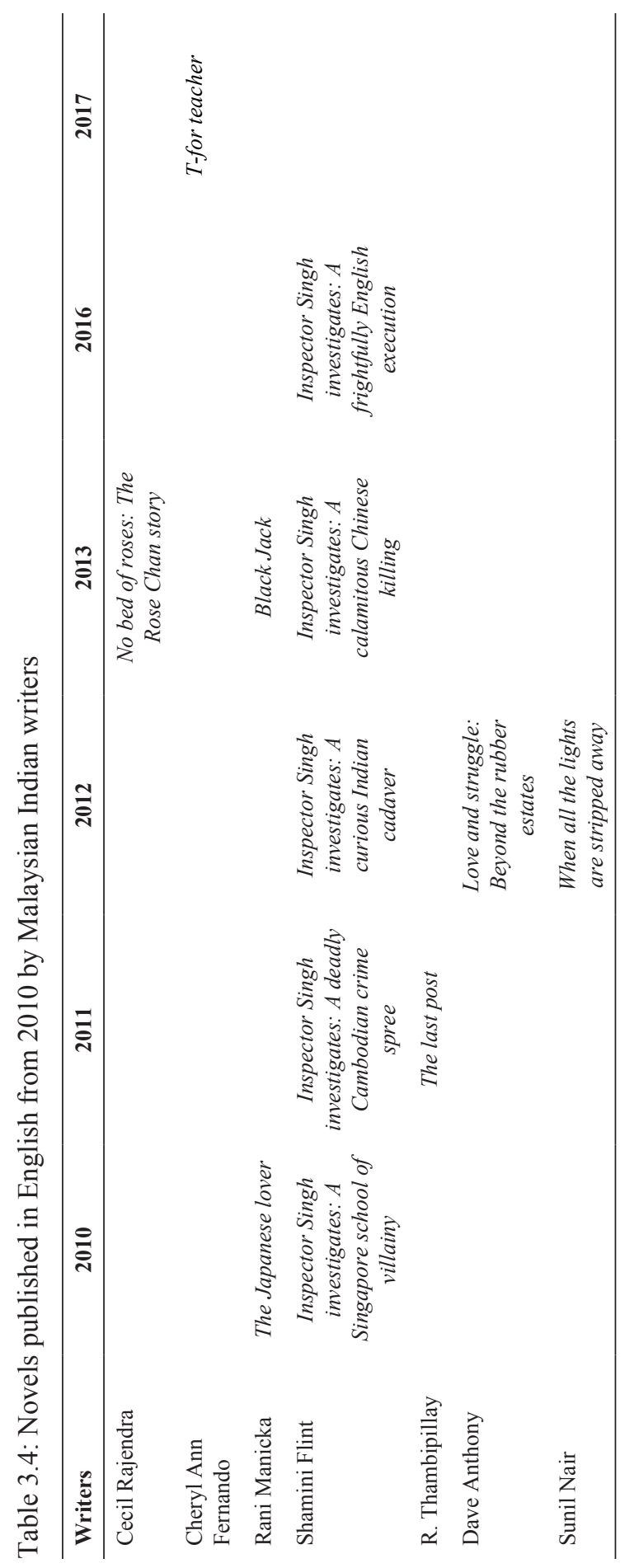




\section{REFERENCES}

Addison, K. 1983. POETRY: Strength underpinned with skill. Far Eastern Economic Review 23 June.

Arasaratnam, S. 1993. Malaysian Indians: The formation of incipient society. In Indian communities in Southeast Asia, eds. K.S. Sandhu and A. Mani, 190-210. Singapore: Institute of Southeast Asian Studies.

Daizal Rafeek Samad. 2001. A heritage of fragments: An interview with Wong Pui Nam. In Malaysian literature in English - A critical reader, eds. M.A. Quayum and P.C. Wicks, 242-253. Kuala Lumpur: Pearson Education Malaysia.

De Souza, D. 2001. The roots of Malay[an] literature in English. In Malaysian literature in English - A critical reader, eds. M.A. Quayum and P.C. Wicks, 2-12. Kuala Lumpur: Pearson Education Malaysia.

Kaur, A. 2003. Sojourners and settlers: South Indians and communal identity in Malaysia. In Community, empire and migration: South Asians in diaspora, ed. C. Bates, 185-205. New Dehli: Orient Longman. https://doi.org/10.1007/978-1-13705743-3_7

Maniam, K.S. 2001 . Fiction into fact, fact into fiction: A personal reflection. In Malaysian literature in English - A critical reader, eds. M.A. Quayum and P.C. Wicks, 263-268. Kuala Lumpur: Pearson Education Malaysia.

. 2012. The life of writers in Malaysia. Nou Hach Literary Journal (July). http:// www.nouhachjournal.net/?p=561 (accessed 13 July 2015).

$\mathrm{Ng}$, I. 2011. The short stories and radio plays of S. Rajaratnam. Singapore: Epigram Books.

Malaysian Examinations Council. 2012. Literature in English: Malaysian higher school certificate examination. Selangor, Malaysia: Malaysian Examinations Council.

Platt, J. and H. Weber. 1980. English in Singapore and Malaysia: Status, features, functions. Kuala Lumpur: Oxford University Press.

Puthucheary, R. 2009. Different voices: The Singaporean/Malaysian novel. Singapore: Institute of South East Asian Studies. https://doi.org/10.1355/9789812309129

Quayum, M.A. 2003. Traversing borders, negotiating identity: Portrayal of the MalaysianIndian diaspora in K.S. Maniam's “The Return”. In The regenerative spirit, eds. N. Bierbaum, S. Harrex and S. Hosking, 91-104. Adelaide: Lythrum Press.

Quayum, M.A. and P.C. Wicks, eds. 2001. Malaysian literature in English - A critical reader. Kuala Lumpur: Pearson Education Malaysia.

Ravichandran, M. 2009. The evolution of the Chitty community of Melaka. JEBAT: Malaysian Journal of History, Politics \& Strategic Studies 36: 1-15.

Sandhu, K.S. 1969. Indian in Malaya: Some aspects of their immigration and settlement (1786-1957). Cambridge: Cambridge University Press.

. 1993. The coming of the Indians to Malaysia. In Indian communities in Southeast Asia, eds. K.S. Sandhu and A. Mani, 151-189. Singapore: Institute of Southeast Asian Studies. https://doi.org/10.1355/9789812305732-010

Tee, K.T. 1999. The exile writes back: Reading Shirley Geok-lin Lim. Paper presented at the Remapping Chinese America: An International Conference on Chinese American Literature, Taipei: Academia Sinica, 11-12 June. 
Tham, S.C. 2001. The politics of literary development in Malaysia. In Malaysian literature in English - A critical reader, eds. M.A. Quayum and P.C. Wicks, 38-66. Kuala Lumpur: Pearson Education Malaysia.

Wong, P.N. 2016. Malachi Edwin Vethamani, complicated lives. Asiatic: IIUM Journal of English Language and Literature 10(2): 259-263. http://journals.iium.edu.my/ asiatic/index.php/AJELL/article/view/874.

Zawiah Yahya. 2003. Nation and narration: The problematics of writing Malaysia in English. In Reclaiming place and space: Issues in new literature, eds. Ruzy Suliza Hashim and G. Subramaniam, 1-15. Bangi: Universiti Kebangsaan Malaysia. 